\title{
The marketing mix in the MSEs of the municipalities of Santiago Ixcuintla, Tuxpan and Ruiz Nayarit
}

\author{
La mezcla de la mercadotecnia en las MyPES de los municipios de Santiago \\ Ixcuintla, Tuxpan y Ruiz Nayarit
}

\author{
VILLARREAL-BAÑUELOS, Erixander $\dagger^{*}$, ALTAMIRANO-ROLDAN, Glafira and GARCIA- \\ GONZALEZ, Frasim
}

Universidad Tecnológica de la Costa

ID $1^{\text {st }}$ Author: Erixander, Villarreal-Bañuelos / ORC ID: 0000-0001-6049-5728, CVU CONACYT ID: 1019548

ID $1^{\text {st }}$ Coauthor: Glafira, Altamirano-Roldan / ORC ID: 0000-0002-8211-4903, CVU CONACYT ID: 1018276

ID $2^{\text {nd }}$ Coauthor: Frasim, García-González / ORC ID: 0000-0002-2352-9009, CVU CONACYT ID: 473802

DOI: $10.35429 / J I E C .2019 .4 .3 .25 .32$

Received March 07, 2019; Accepted June 30, 2019

\begin{abstract}
The growth of micro and small enterprises (MSEs) in Nayarit, as well as in the country has been increasing, however, due to the same characteristics of informal and unstructured conformation of these companies, they do not grow financially and most of them spend their time subsisting as micro businesses. That is why this analysis focuses on knowing if microentrepreneurs apply marketing strategies and if so, what kind of strategies do they implement to strengthen their businesses. The main purpose of this study are the MSEs of the municipalities of Santigo Ixcuintla, Tuxpan and Ruiz of the state of Nayarit, from which relevant information was obtained by applying surveys directly with the owners or directors of the companies, regarding the application of marketing strategies. As a result, we can observe that most entrepreneurs do not implement structured or formalized strategies, however, they develop basic strategies that meet customer satisfaction according to their market segment such as: product tests prior to their launch, the creation of brands so that their clients can identify them, pricing based on competition and development of credit strategies for their customers. They develop the most appropriate strategies according to the type of product, since they sell it directly to the final consumer and a considerable percentage consider selling to intermediaries. The implementation of promotional and advertising strategies is not clear; however, entrepreneurs express that they implement strategies that allow them to stay in the minds of consumers. This does not mean that the strategies are adequate or that they have favorable results in their entirety since they are not professionally structured.
\end{abstract}

MSEs, Marketing mix, Strategies

\begin{abstract}
Resumen
El crecimiento de las micro y pequeñas empresas (MyPES) en Nayarit, así como en el país ha ido en incremento, sin embargo, por las mismas características de la conformación informal y no estructurada de estas empresas es que no crecen financieramente y la mayor parte de su vida la pasan subsistiendo como micro empresas. Es por eso que se consideró el desarrollo de este análisis para saber si los microempresarios aplican estrategias mercadológicas y si es así que tipo de estrategias implementan, que les permitan potenciar sus negocios. El objeto principal de este estudio son las MyPES de los municipios de Santigo Ixcuintla, Tuxpan y Ruiz del estado de Nayarit, de las cuales se obtuvo información relevante mediante la aplicación de encuestas directamente con los dueños o directores de las empresas, información con respecto a la aplicación de estrategias mercadológicas.Derivado de esto como resultado podemos observar que la mayoría de los empresarios no implementan estrategias estructuradas o formalizadas, sin embargo, desarrollan estrategias básicas que cumplen con la satisfacción del cliente según su segmento de mercado como lo son: pruebas de productos previas al lanzamiento de estos, la creación de marcas para que sus cliente puedan identificarlos, fijación de precios con base a la competencia y desarrollo de estrategias de crédito para sus clientes. Desarrollan las estrategias más adecuadas según el tipo de producto, ya que lo comercializan directamente al consumidor final y un porcentaje considerable considera vender a intermediarios. La implantación de estrategias promocionales y publicitarias no queda clara, sin embargo, los empresarios expresan que implementan estrategias que permiten mantenerse en la mente de los consumidores, esto no significa que las estrategias son las adecuadas ni que tienen resultados favorables en su totalidad ya que estas no están estructuradas profesionalmente.
\end{abstract}

MSEs, Marketing mix, Strategies

Citation: VILLARREAL-BAÑUELOS, Erixander, ALTAMIRANO-ROLDAN, Glafira and GARCIA-GONZALEZ, Frasim. The marketing mix in the MSEs of the municipalities of Santiago Ixcuintla, Tuxpan and Ruiz Nayarit. JournalInternational Economy. 2019. 3-4: 25-32

\footnotetext{
* Correspondence to Author (evillarreal@utdelacosta.edu.mx)

$\dagger$ Researcher contributing first Author.
} 


\section{Introduction}

For this project, we considered to conduct the analysis of the implementation of the marketing mix strategies such as: product, price, term or distribution and promotion within the municipalities of Santiago Ixcuintla, Tuxpan and Ruiz, Nayarit, specifically in the micro enterprises of this region and how the micro entrepreneurs select these strategies with the objective of increasing their profits; however, there is a variable that cannot be omitted to make a deeper analysis such as the academic degree of the micro entrepreneurs.

One of the main problems that arise in microenterprises is that there is no formality within the organization, since more than $58 \%$ of the entrepreneurs have only complied with the basic level of education, only $10 \%$ have achieved a higher level, leaving aside the fact that the strategies implemented do not have a professional structure.

As it is well known, in Mexico more than $90 \%$ of the companies are micro, according to data from the National Institute of Geography and Statistics (INEGI), and the economic percentage is not very representative, however they are generators of jobs and regional economic growth. Within the selected zone of influence, it should be highlighted that there are 7542 companies according to INEGI data, of which 7219 are micro companies, more than $95 \%$ is our object of study.

Knowing which are the strategies that these entrepreneurs implement and comparing them with the increase in profits will provide a broad overview to make decisions and present solutions that allow the development of current and better structured marketing strategies that can continue to encourage the growth of the companies.

\section{Theoretical framework}

\section{MSEs}

Traditionally, companies are classified according to their size into small, medium and large. As we know, the first two are referred to as SMEs (small and medium-sized enterprises). In addition, a fourth has recently been added to these three groups: micro-enterprises, which are also included in MSEs.
There are several criteria for this classification of companies. Some of them are the following:

Economic criterion: this classifies companies according to their turnover, i.e. the income obtained from sales.

Technical criterion: this is the level of technology, i.e. capital innovation.

Equity criterion: this is based on the assets that the companies have: goods, rights and obligations.

Organizational criterion: refers to the number of workers in the company and its organization. (BBVA, 2019)

In Mexico, $94.3 \%$ of new establishments are micro businesses, according to data from the National Institute of Geography and Statistics. (INEGI, 2015)

(Fernandez, 2007) mentions that microenterprises are the largest group of organizations in our country. They generally lack a formal organizational structure and do not always have competitiveness studies, so they do not know the market share of their competitors. They are made up of between 2 and 10 people depending on the number of activities they carry out. They generate enough income to cover their costs and obtain a profit margin.

The small company has a much more formal structure than the micro company; they have a minimum share of the market, but they have a presence in front of their competitors. It is estimated that $65 \%$ of small and medium enterprises in Mexico are family businesses, of which $80 \%$ do not have any type of certification and about $50 \%$ do not use quality or productivity techniques. (Garibay, 2016)

Although what they do may sound "basic", microenterprises are of great importance for the country, because they, together with small and medium enterprises, generate $72 \%$ of employment - particularly microenterprises are attributed $41.8 \%$ of total employment - and contribute $52 \%$ of the country's Gross Domestic Product, as highlighted by data from the Condusef. 
Although their presence is positive, it should be noted that it is not easy to maintain them, because, as highlighted by data from the organization Mexico Emprende, "the competitiveness and productivity of microenterprises, especially the traditional type, is being threatened by the incorporation of modern business concepts that demonstrate: Limited professionalization, disorderly growth, technological backwardness, high energy consumption, neglected and unhealthy image, informal management and limited access to financing". (Merca2.0, 2018)

\section{Municipal Context}

The state of Nayarit is the fourth with the lowest number of economic units in the country, with a record of 57905, only surpassing the states of Campeche, Baja California Sur and Aguascalientes, (INEGI, 2018).

The municipality of Santiago Ixcuintla has a population of 97820 inhabitants (INEGI, 2016), the average age of the population is 30 years; for every 100 people in productive age there are 58 in economic dependency age; the average number of inhabitants per house is 3.4 , $6.2 \%$ of the population has no educational instruction, $64.7 \%$ has basic education, $18.7 \%$ upper secondary education and $10 \%$ higher education. The economically active population (PEA) is $49.2 \%$ and the non-active population is 50.8\% (INEGI, 2016). The municipality has 4399 economic units of which 4362 are MSEs, representing 99.1\% (INEGI, 2018).

The municipality of Ruiz has a population of 24743 inhabitants (INEGI, 2016), half of the population is 25 years old; for every 100 people in productive age, there are 63 in economic dependence age; the average number of inhabitants per house is $3.7,8.1 \%$ of the population has no educational instruction, $62.4 \%$ has basic education, $20.3 \%$ has upper secondary education and $9.1 \%$ higher education. The economically active population (PEA) is $44.4 \%$ and the non-active population is $55.5 \%$ (Inegi, 2016). The municipality has 1027 economic units of which 1023 are MSEs, representing 99.1\% (Inegi, 2018).
The municipality of Tuxpan has a population of 30565 inhabitants (Inegi, 2016), half of the population is 30 years old; for every 100 people in productive age there are 55 in economic dependence age; the average number of inhabitants per house is 3.3 people, $6.1 \%$ of the population has no educational instruction, $56.7 \%$ has basic education, $24.4 \%$ has upper secondary education and $12.5 \%$ higher education. The PEA is $49.4 \%$ and the non-active is $50.3 \%$ (Inegi, 2016). The municipality has 2115 economic units of which 2106 are MSEs, representing $99.5 \%$ (Inegi, 2018).

\section{Marketing}

For (Kotler \& Armstrong, 2012) marketing is the management of profitable customer relationships and the process by which companies create value for customers and establish strong relationships to obtain value from them in return. Today, marketing should be understood not in the archaic sense of making a sale ("talking and selling"), but in the modern sense of meeting customer needs.

(Fischer \& Epejo, 2011) define marketing as the process of planning, executing and conceptualizing pricing, promotion and distribution of commodity ideas and terms to create exchanges that meet individual and organizational objectives.

\section{Marketing Mix}

Kotler and Armstrong define marketing mix as "the set of controllable tactical marketing tools that the company combines to produce a desired response in the target market. The marketing mix includes everything the company can do to influence demand for its product."

The American Marketing Association's "Dictionary of Marketing Terms" defines marketing mix as those "controllable variables that a company uses to achieve the desired level of sales in the target market" (AMA).

According to authors Kotler, Armstrong and Belch G., marketing mix can be explained by 4 variables, which are: 
Product: This refers to the goods, products, services, organizations, etc., that are offered in a particular market. Within this category we can talk about the product portfolio, their differentiation, as well as the brand and the presentation.

Price: This is the exchange value of the product and is established prior to the launch. The price is set without any studies that determine if the product will be acquired by the public, as well as the price of its competitors.

Place: Also known as distribution, this section seeks to ensure that the product reaches the consumer. Here, different distribution channels are used, as well as distribution planning and various marketing and merchandising techniques.

Promotion: This category includes all the communication strategies the purpose of which is to spread a message to the audience who hopefully will become consumers of the brand's products.

\section{Marketing mix strategies:}

(Kotler P., 2008), it is the marketing logic that the company uses to establish fruitful relationships. Through market segmentation, target market determination, and positioning, the company decides which customers it will serve and how. It will identify the total market, then divide it into small segments, then select the most promising segments and then focus on serving and satisfying those segments.

(Mullins, Walker, \& Larreche, 2007), the main focus of a marketing strategy is to effectively allocate and coordinate marketing resources and activities to achieve the company's goals within a specific market; therefore, the decisive issue with respect to the scope of a marketing strategy is to specify the target markets for a particular product or product line. Researchers have identified general categories of competitive strategies at the business level based on general patterns of purpose, practice and performance of different businesses. Michael Porter distinguishes three strategies - or competitive positions - that businesses seek to obtain and maintain competitive strategies in their various product markets:
(1) overall cost leadership; (2) differentiation, creating customer value in perceptions of superior product, design, or service quality; and (3) focus, in which the business avoids direct confrontation with its primary competitors by concentrating on narrowly defined market niches. Porter describes companies that lack a distinctive strategy as "stuck in the middle" and predicts that they will perform poorly. 4 Robert Miles and Charles Snow identified another set of business strategies based on a projected percentage of product market development (new product development, new market penetration). 5 They classify the business units into four strategic types: search engines, advocates, analyzers, and reactors.

\section{Graphics analysis}

\section{Product/Services}

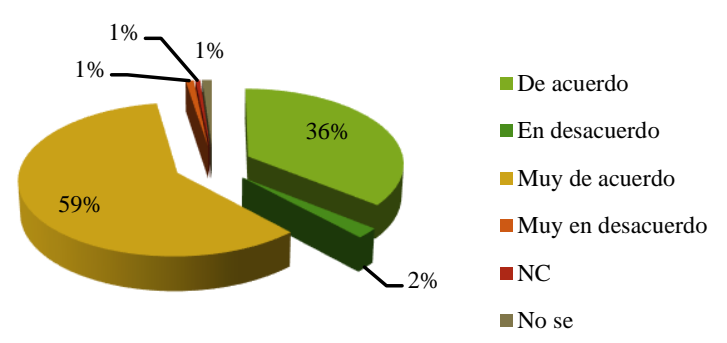

Graph 1 I focus mainly on giving a very good service to my customers

Source of reference: Relayn 2018 database, prepared by the authors

Of all the microentrepreneurs surveyed, 95\% focus on providing good service to their clients as part of their strategies, there are different intangible but measurable strategies that allow for client satisfaction and preference. 


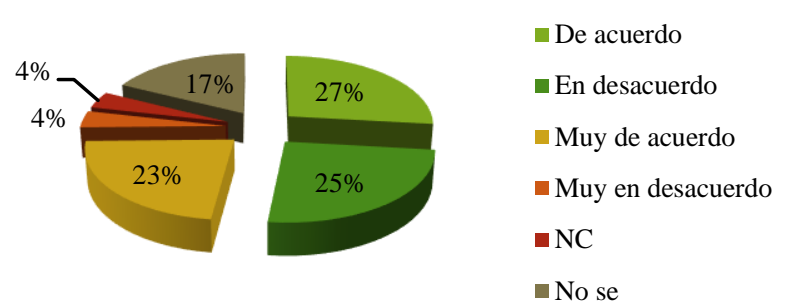

Figure 2 I seek to create, develop and use a brand so that my clients identify my company

Source of reference: Relayn 2018 database, prepared by the authors

$50 \%$ of those surveyed seek to create or use a brand so that their clients can identify them and thus create a positioning in the minds of consumers, however $25 \%$ of microentrepreneurs do not do so and their clients do not identify them with a brand of their own, an element that is preferred by the competition.

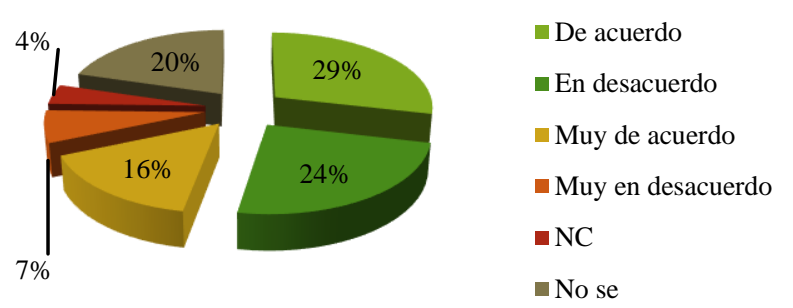

Figure 3 I test my products or services before launching them to the market

Source of reference: Relayn 2018 database, prepared by the authors

$45 \%$ of entrepreneurs test their products before launching them on the market to measure customer or prospect acceptance and $31 \%$ do not pre-test for feasibility analysis.

\section{Price}

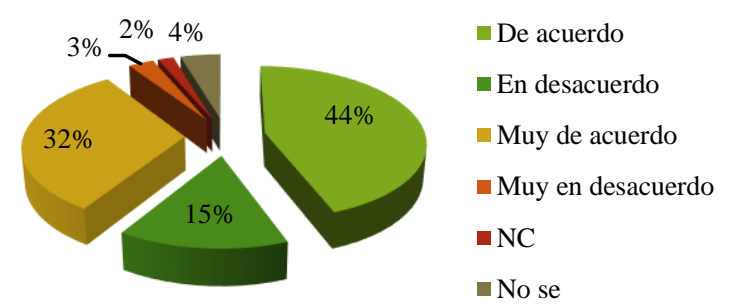

Figure 4 I set the prices of my products and services based on my customers and my competition

Source of reference: Relayn 2018 database, prepared by the authors
$76 \%$ take into account their competition and their customers when setting the price of their products, considering that the market is changing and that competition is constantly increasing; however, $15 \%$ do not consider any strategy when setting their precise price.

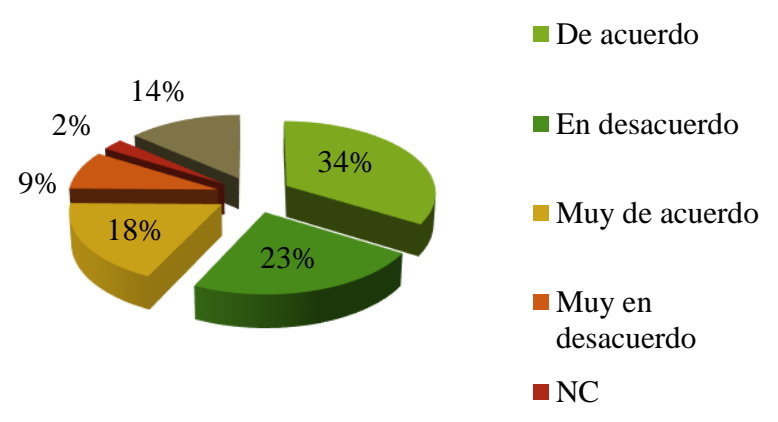

Figure 5 My strategy is to give credit to my customers Source of reference: Relayn 2018 database, prepared by the authors

As strategies to consolidate and maintain their clients, $52 \%$ of the entrepreneurs grant credit to their clients and $32 \%$ do not agree to apply this type of strategy.

\section{Place/Distribution}

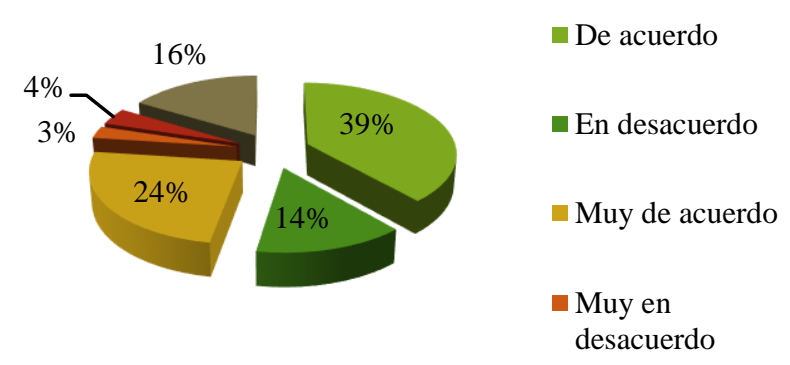

Figure 6 As a distribution strategy, I sell mainly to the end user

Source of reference: Relayn 2018 database, prepared by the authors

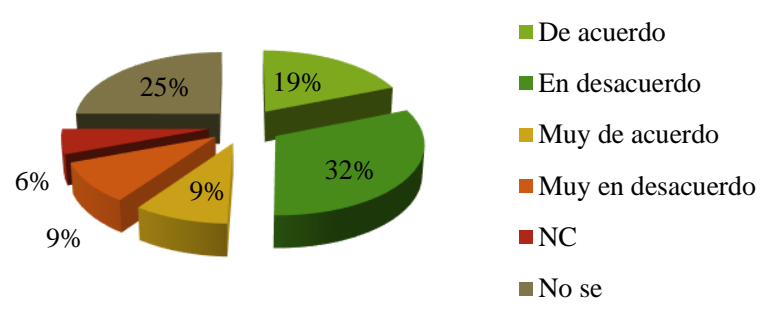

Figure 7 As a distribution strategy, I sell mainly to wholesalers or intermediaries

Source of reference: Relayn 2018 database, prepared by the authors 
As a distribution strategy, $63 \%$ of microentrepreneurs sell their products to the final consumer and $28 \%$ sell their products to intermediaries, depending on the type of product being marketed.

\section{Promotion}

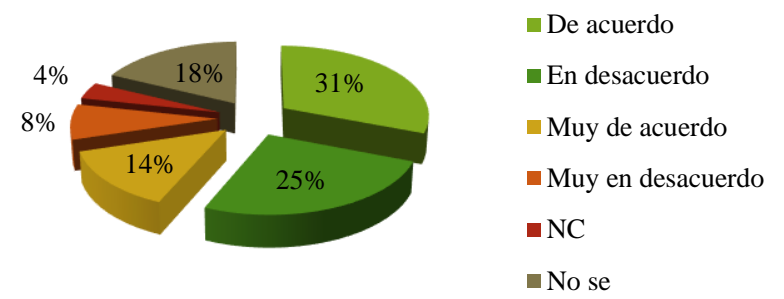

Figure 8 I carry out advertising and promotional activities on my product or service

Source of reference: Relayn 2018 database, prepared by the authors

It is observed that $46 \%$ carry out advertising activities and promotional strategies and $33 \%$ do not implement any type of promotional strategies on their products; although it is not specified what type of strategies they implement, but the mere fact of developing some basic ones allows them to be competitive.

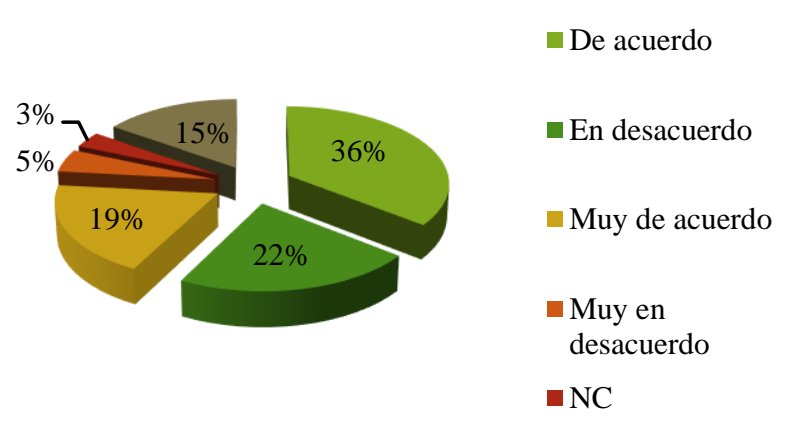

Graph 9 I carry out concrete actions to make my clients loyal to the company

Source of reference: Relayn 2018 database, prepared by the authors

$55 \%$ of the entrepreneurs carry out strategies that allow them to have the loyalty of their clients and only $27 \%$ do not carry out this type of activity.

\section{Utilities}
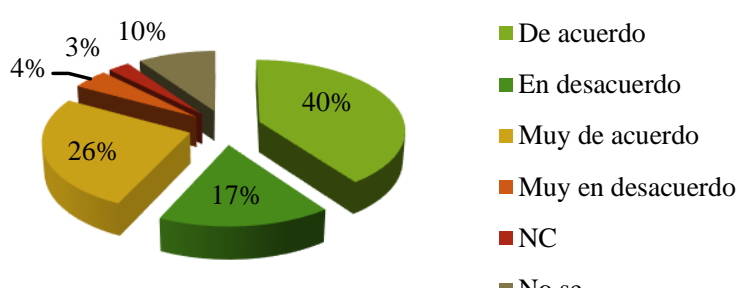

No se

Figure 10 There is strong competition in my company's sector

Source of reference: Relayn 2018 database, prepared by the authors

Of all the entrepreneurs surveyed, $66 \%$ consider that there is strong competition in the market and only $21 \%$ do not consider that they have strong competition.

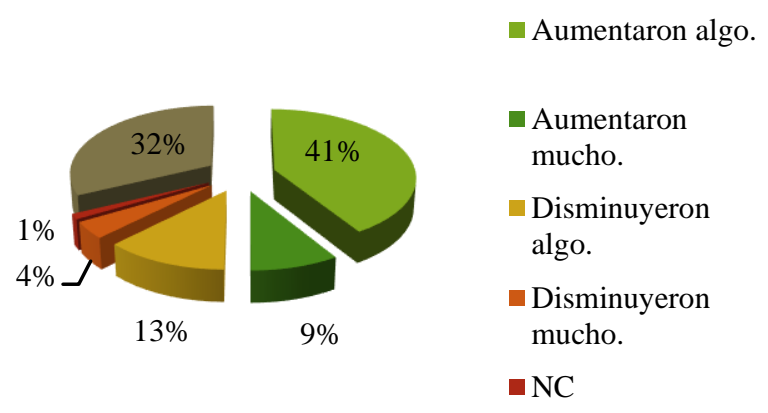

Figure 11 In the last three years, what has happened to your company's profits?

Source of reference: Relayn 2018 database, prepared by the authors

In the last 3 years, the profits of $50 \%$ of the microentrepreneurs increased, 32\% stayed the same and $17 \%$ decreased their profits.

\section{Methodology to be developed}

The research was carried out on MSE directors in the municipalities of Santiago, Tuxpan and Ruiz, in the northern part of the state of Nayarit, through a non-experimental quantitative analysis in a correlational cross-sectional way (Hernández, Fernández, \& Baptista, 2010), this is part of a larger study at the national level. The instrument used was a survey made up of 225 items (Posada, Aguilar, \& Peña, 2018), 545 microenterprise directors from the municipalities in question participated; for each municipality a representative sample was considered, with a desired confidence level of $95 \%$, and a maximum margin of error of $5 \%$. (Posada, Aguilar, \& Peña, 2018) 
The collection of information was carried out by students trained in both the application of the questionnaire and its capture on the platform. The information was collected from February 13 to March 10, 2018 (Villarreal, Rodriguez, Quezada, \& Ramirez, 2018)

For this study, only one item was considered in relation to marketing and the application that directors make in microenterprises. Eleven questions were considered for analysis, a Likert scale was used with the values: 5 very much in agreement, 4 in agreement, 3 in disagreement, 2 very much in disagreement and 1 do not know/not applicable.

\section{Results}

This study allows to have a vision of the application of the marketing strategies in the MSEs of the municipalities of Santiago Ixcuintla, Tuxpan and Ruiz, as it is mentioned by the magazine Merca 2.0, "The competitiveness and productivity of the micro companies, especially the traditional ones, is being threatened by the incorporation of modern concepts of business: Limited professionalization, disorderly growth, technological backwardness, high energy consumption, careless and unhealthy image, informal administration and limited access to financing," however, according to the results obtained, it can be observed that the trends have changed, although the educational level does not justify it, the entrepreneurs have made an effort to be more competitive, in table 1 of the annexes, it can be seen that $28.62 \%$ of the businessmen finished the third grade of secondary school, followed by $17 \%$ who finished the high school level and in third place $12 \%$ finished primary school and only $10 \%$ have higher level studies.

As a result, we can see that most of the entrepreneurs do not implement structured or formalized strategies, however, they develop strategies that allow customer satisfaction such as: testing products before launching them, $45 \%$ of the entrepreneurs apply it and this contributes to better market acceptance and investment care, $50 \%$ of the entrepreneurs develop and enhance their brands so that their customers can identify them and thus have greater market penetration, pricing based on competition and development of credit strategies for their customers.
They develop the most appropriate strategies according to the type of product, since they market it directly to the final consumer and a considerable percentage consider selling to intermediaries. The implementation of promotional and advertising strategies is not clear; however, entrepreneurs say that they implement strategies that allow them to stay in the minds of consumers, because competition is increasing. Derived from the implemented strategies, $50 \%$ of the microentrepreneurs expressed that they had increased their profits in the last 3 years, which tells us that there is a correlation between the growth of profits and the implementation of marketing strategies, which leads us to be able to perfect and increase this type of strategy to gradually increase the profits of the entrepreneurs in the area of influence.

\section{Annexes}

\begin{tabular}{|l|r|r|}
\hline \multicolumn{1}{|c}{ Row labels } & $\begin{array}{r}\text { Count of } \\
\text { 21) Last } \\
\text { year of } \\
\text { studies } \\
\text { complete } \\
\text { d: }\end{array}$ & $\begin{array}{r}\text { Count of } \\
\text { 21) Last } \\
\text { year of } \\
\text { studies } \\
\text { complete } \\
\text { d: } 2\end{array}$ \\
\hline a) 1st Grade Primary. & 12 & $2.20 \%$ \\
\hline b) 2nd Grade Primary. & 5 & $0.92 \%$ \\
\hline c) 3rd Grade Primary. & 14 & $2.57 \%$ \\
\hline d) 4th Grade Primary. & 7 & $1.28 \%$ \\
\hline e) 5th Grade Primary. & 6 & $1.10 \%$ \\
\hline f) 6th Grade Primary. & 65 & $11.93 \%$ \\
\hline (g) 1st Grade Secondary. & 17 & $3.12 \%$ \\
\hline h) 2nd Grade Secondary. & 16 & $2.94 \%$ \\
\hline (i) 3rd Grade Secondary. & 156 & $28.62 \%$ \\
\hline j) 1st Grade High School or Technical School. & 39 & $7.16 \%$ \\
\hline k) 2nd Grade High School or Technical School. & 12 & $2.20 \%$ \\
\hline L) 3rd Grade High School or technical. & 93 & $17.06 \%$ \\
\hline m) More than one year of university without a & & \\
degree. & 19 & $3.49 \%$ \\
\hline n) Higher technical university degree. & 21 & $3.85 \%$ \\
\hline NC & 4 & $0.73 \%$ \\
\hline o) Graduate or engineering degree. & 54 & $9.91 \%$ \\
\hline (q) Master's degree. & 4 & $0.73 \%$ \\
\hline (r) Doctoral degree. & 1 & $0.18 \%$ \\
\hline (blank) & & $0.00 \%$ \\
\hline Grand total & $\mathbf{5 4 5}$ & $\mathbf{1 0 0 . 0 0}$ \\
\hline & & \\
\hline & &
\end{tabular}

Table 1 Last grade of study completed by employers Source of reference: Relayn 2018 database, prepared by the authors

\section{Acknowledgement}

The authors thank Universidad Tecnológica de la Costa for always promoting the development of the institution and the team of professors, with the primary objective of fostering and contributing to the development of the northern zone of the state of Nayarit, aware of the great potential that exists in these municipalities. In addition, these strategies stimulate the growth of students to continue developing techniques, tools and strategies in conjunction with the university, entrepreneurs and society in general.

VILLARREAL-BAÑUELOS, Erixander, ALTAMIRANO-ROLDAN, Glafira and GARCIA-GONZALEZ, Frasim. The marketing mix in the MSEs of the municipalities of Santiago Ixcuintla, Tuxpan and Ruiz Nayarit. Journal- International Economy. 2019 


\section{Conclusions}

Ignorance of marketing strategies and their application is one of the many factors that affect microentrepreneurs, derived from lack of knowledge and preparation to apply them. In the investigation it was possible to identify some of the strategies of the marketing mix that the micro businessmen of the municipalities of Santiago Ixcuintla, Tuxpan and Ruiz, Nayarit implement to achieve positioning and the loyalty of their clients. It is noteworthy that the businessmen do not have the professional formation to develop suitable and specific strategies for their company, nevertheless, the strategies implemented with respect to the test of products before launching, design and diffusion of a brand to position themselves, the adequate fixing of prices considering their clients and the competition, the selection of final clients and intermediaries according to the type of product that is commercialized, as well as the implementation of advertising and promotional strategies to make public their framework, product and company, result in the increase of profits in the last 3 years in 50\% of the MSEs, however there is a representative percentage (32\%) that have maintained their sales, but there are no indicators or parameters that allow to monitor and measure with certainty the adequate implementation of the strategies already mentioned.

Derived from this analysis, it is recommended to develop basic strategies of training in marketing, to achieve the implementation in all the micro companies and with indicators that measure adequately the growth in each one of the strategies and variables mentioned before; as part of an educational institution, it is proposed to develop workshops to offer basic and simple information for the implementation of marketing strategies that promote positioning, increase in sales and satisfaction of the client.

\section{References}

AMA. (s.f.). American Marketing Association. Obtained from https://www.ama.org

BBVA. (2019). BBVA. Obtained from Clasificación de empresas según su tamaño: https://www.bbva.es/general/finanzasvistazo/empresas/clasificacion-de-empresaspor-tamano/index.jsp
Fernandez, R. (2007). Manual para elaborar un plan de mercadotecnia. Mexico : McGrawHill.

Fischer, L., \& Epejo, J. (2011). Mercadotecnia . Mexico: Mc Graw Gill.

Garibay, J. (2016). Mercadotecnia. Merca 2.0.

Hernández, R., Fernández, C., \& Baptista, P. (2010). Metodología de la Invesigación. Mexico: Mc Graw Hill.

INEGI. (2015). Instituro Nacional de Estadística y Geografía. Obtained from INEGI: https://www.inegi.org.mx/

Kotler, P. (2008). Marketing. Mexico : Pearson.

Kotler, P., \& Armstrong, G. (2012). Marketing. Mexico: Pearson.

Merca2.0, M. e. (2018). Radiografía de las microempresas en México. Merca 2.0.

Mullins, J., Walker, O., \& Larreche, J. (2007). Administración de Marketing. Mexico: Mc Graw Hill.

Posada, R., Aguilar, Ó., \& Peña, N. (2018). Metódo. En S. Delgado, Potencial tecnologico de las micro y pequeñas empresas latinoamericanas (pp. 23-24). Mexico: Fontamara. 